\title{
Vnímání jinakosti dětmi na prvním stupni základních škol
}

\author{
Miluše Vítečková, Miroslav Procházka, Marie Najmonová
}

\author{
Jihočeská univerzita v Českých Budějovicích, Pedagogická fakulta, \\ Katedra pedagogiky a psychologie
}

Redakci zasláno 25. 2. 2018 / upravená verze obdržena 8. 6. 2018 /

k uveřejnění přijato 8. 6. 2018

\begin{abstract}
Abstrakt: Cílem článku je představit vnímání jinakosti dětmi na 1. stupni základní školy na základě využití podnětů z práce s příběhem v hodině českého jazyka. Příspěvek lze také vnímat jako podklad pro výukovou praxi a jako příklad toho, jak pracovat s tématy jinakosti a odlišnosti na 1. stupni základní školy. Text obsahuje výsledky výzkumného šetření realizovaného ve 12 třídách 1 . stupně základních škol (3.-5. třídy). Jde o analýzu videozáznamů 12 vyučovacích hodin, verbálních projevů žáků, jejich transkriptů, a to v průběhu celé vyučovací jednotky, v níž děti pod vedením učitelky pracují s uceleným didaktickým materiálem. Dětem jsou kladeny otázky týkající se jejich nazírání na odlišnost, a to v kontextu obsahu př́iběhu. Text podstatou svého př́íběhu dává prostor pro vyjádření pocitů spojených s odlišností, vytváří podněty pro argumentaci postojů orientovaných k chování se v situaci nepřijetí okolím. Výzkumné šetření se zaměřuje na tyto otázky: jak žáci 1. stupně vnímají odlišnost, jakou mají subjektivní zkušenost s odlišností, jaké jsou jejich návrhy řešení situace v případě nepřijetí okolím, jaký je jejich pohled na druhé nepřijímající odlišnost. Vzhledem k tomu, že jde při práci s konkrétním textem i o čtení s předvídáním, je dalším analyzovaným tématem navrhované dokončení př́iběhu. Z výsledků výzkumného šetření vyplynulo, že žáci na 1. stupni přijímají odlišnost bez větších problémů, spíše se hůře vyrovnávají s nespravedlností. V situacích, kdy se sami setkávají s nepřijetím, výzkum naznačuje, že i přes prožívané obtíže v kolektivu žáci preferují setrvání v prostředí, které znají.
\end{abstract}

Klíčová slova: jinakost, práce s příběhem, sociální učení, sociální dovednosti, žák 1. stupně základní školy

Rozmanitost současného světa, charakteristického dialektickým střetáváním bezbřehé tekutosti s narůstajícím vlivem nových autorit, individualismu s proklamovanou protýmovostí, ideovým chaosem s vyvoláváním starých démonů národnostních hodnot, se stále výrazněji zrcadlí v současné škole. Ta se stává prostředím, ve kterém se mísí životy dětí z různých typů rodin, 
dětí zdravých a postižených, dětí různých kultur a náboženství i s různým socioekonomickým statusem. Škola se stává prostředím, do kterého se plně promítá pestrost a rozmanitost našeho lidského života. Jinakost je pak odrazem těchto změn v každodennosti lidských vztahů.

Zaměříme-li se znovu na dnešní školu, zaznamenáme živé diskuze o prosazování principů společného vzdělávání a s ním se někde na pozadí objevuje potřeba nalezení optimální míry mezilidské tolerance a nastolení mechanismů překonávání nenávisti. Klíčovým momentem je přitom ovlivnění postojů dětí, a to pokud možno již od začátku jejich školní docházky. Článek se proto soustředí na nalezení odpovědi na to, jak vidí odlišnost žáci 1. stupně základní školy, jakou mají s odlišností zkušenosti, jak argumentují řešení v př́ípadě nepřijetí okolím, jaký je jejich pohled na druhé nepřijímající odlišnost a jaký by mohl podle nich mít jimi diskutovaný př́běh řešení, jak by mohl dopadnout.

\section{Jinakost, odlišnost ve speciálně pedagogickém kontextu}

K přesnému vymezení problematiky jinakosti a odlišnosti můžeme využít poměrně rozsáhlou literaturu. Na tuto problematiku se přitom nahlíží v diskursu rozmanitých oborů - sociologie, speciální pedagogiky, sociální pedagogiky, psychologie a psychopatologie, medicíny aj.

V článku je na jinakost a odlišnost pohlíženo jako na synonyma ve speciálněpedagogickém kontextu. Jak uvádí Prouzová Květoňová (2011), tyto termíny vystihují předmět zájmu speciální pedagogiky. Termíny se spojují s lidmi s postižením, znevýhodněním, zahrnují ale i příslušníky národnostních či náboženských menšin, uprchlíky. Zároveň dodává, že tyto pojmy mají v obecném významu pro většinovou společnost negativní konotaci. V lidech vyvolávají projevy odporu, nepřátelství nebo nedůvěru k odlišnému a zosobňují nevědomý strach ze všeho cizího. Kolářová (2012, s. 11) zmiňuje, jak jinakost nutí „zírat“. V našem multikulturním světě se stále může stávat, že se odlišnost zdůrazňuje, aby budila údiv, je exotizována a sentimentalizována. Autorka uvádí, že

diváctvu je dovoleno, aby se upřeným pohledem odlišnosti zmocňovalo, a zároveň distancovalo od toho, co vidí. Tento druh upřeného pohledu je způsobem vyznačení hranic, způsobem začlenění a zároveň vyčlenění odlišnosti pozorovaných abnormálních, defektních a postižených těl. (Kolářová, 2012, s. 11) 
Pokud je spojena jinakost s ošklivostí, jak zmiňuje Eco (2007), doprovázejí ji pocity nevole, ale i odpor, děs či hrůza, naopak v synonymech ke slovu krása můžeme vycítit jistou nezainteresovanou hodnoticí reakci. Velmi zajímavý pohled na odlišnost zmiňuje Davis (2012). Místo, aby se zaměřoval na koncept odlišnosti kvalifikovaný jako „postižení“, věnuje se konstruktu normality. „Problémem“ dle něho není člověk s odlišným tělem, ale problematické je to, jakým způsobem se skrze konstruování normality problém „postiženého“ vytvárí. Slovo „normální“ se objevuje ve smyslu něčeho běžného, standardního až kolem poloviny 19. století, předchází mu výraz „ideál“.

Slowík (2010) si všímá komunikace lidí s postiženým člověkem, při níž dochází k nepartnerskému přístupu. To, co chybí, je přítomnost informací, které o jedincích s postižením referují jako o docela obyčejných lidech. $\mathrm{S}$ tím souvisí strach a ostych doprovázející emoční složku lidských postojů a zmenšující se v souvislosti s kvalitní informovaností. To potvrzuje Vágnerová (1999), která dává do souvislosti postoje společnosti k lidem, kteří jsou sociokulturně či etnicky odlišní, s nízkou informovaností, která vede vždycky $\mathrm{k}$ převaze emocionální složky nad rozumovým hodnocením. Právě z tohoto důvodu považujeme jako velmi př́nosnou práci s př́iběhem, jenž otevírá možnost, jak přibližovat jinakost. Jde o prostor, ve kterém žák získává nejen nové informace, rozvíjí se jeho empatie, ale také v něm vzniká místo pro formování postojů, hodnot. Je možné se opírat o Alexandra (2006), který uvádí principy multikulturalismu, $v$ němž je pohlíženo na identitu s akcentem nikoli na „Vydělování", ale naopak na „sbližování". Okrajové vlastnosti, odlišnosti, jsou v tomto př́ípadě vnímány jako variace svobody. Podle Přibáně (1997) činí v postmoderní společnosti jedince liberálními právě ochrana všeobecné plurality a respektování práva na odlišnost a jinakost. Toto je spjato s principem tolerance a úcty $\mathrm{k}$ druhému.

\section{Sociální učení jako cesta k respektování jinakosti a odlišnosti}

Jinakost, odlišnost, různorodost třídních a školních kolektivů staví učitele do nové situace, kdy je třeba začít s tímto tématem u dětí výchovně pracovat. Nestačí pouze vyložit příklady popisující odlišnosti, je nutné především rozvíjet osobnostní a sociální kompetence dětí a učit je toleranci, respektu, empatii, morálce. Jak uvádí Cihá a Preissová Krejčí (2012), strach z odlišnosti, který je považován za přirozený a vlastní všem lidským tvorům, nemůže 
být „překonáván“ popíráním odlišnosti. Zmiňují zážitkovou pedagogiku, v jejímž rámci lze záměrně navozovat situace, které jsou provázeny prožíváním emocí, a současně se s emocemi pracuje tak, aby se podpořily pozitivní postoje a aby se navodila změna $v$ prípadě negativních postojů. Mluvíme mimo jiné o tzv. aktivním sociálním učení, v němž je klíčová sebereflexe, která vzniká při sdílení odlišného vnímání zážitku. Cihá (2012) vidí další cestu k respektu jinakosti a odlišnosti např́iklad v empatii, dále zmiňuje důležitý fakt, kdy se opírá o názory některých autorů, kteří vidí v krizi identity příčinu pozdějšího rasismu.

Velký význam je z hlediska stimulace emocionální stránky osobnosti přikládán věku mezi třetí a pátou tř́́dou. Čačka (1999) zdůrazňuje, že v dětství je duševní dění mimořádně schopné zpracovávat i velmi složité sociální vztahy imaginativně-emotivní, a to převážně podvědomou cestou. City se v tomto období začleňují do osvojovaných postojů. Ty pak urychlují orientaci a zabezpečují soulad prožívání a reagování v rámci komunity, zahrnují kognitivní, prožitkovou i konativní složku. Herényiová (2006) upozorňuje, že k identifikaci vlastních pocitů je možné dojít pomocí úloh a podnětů k tvořivému myšlení, ale i tím, že se učitel s žáky věnuje otázkám prožívání, postojů, potřeb, hodnot a vztahů, které se učí vyjadřovat a o kterých se diskutuje.

Výše uvedené vývojové aspekty nás vedly $\mathrm{k}$ výběru věkové struktury výzkumného souboru. V námi zvoleném vývojovém období, tedy mezi osmým a jedenáctým rokem, se pro vytváření vlastní identity stává školní prostředí velmi významným. Podle Thorové (2015) dítě ještě sice není schopno integrovaného sebepojetí, ale setkává se s hodnocením od spolužáků, učitelů, je srovnáváno s širším okolím, má možnost porovnávat své výkony s ostatními dětmi. Začíná si uvědomovat i své slabé stránky a snaží se je integrovat do sebepojetí. Pozitivní skutečností, se kterou je možné dále pracovat, je to, že okolo devíti a deseti let projevují děti více soudržnosti a solidarity. Jde o období, kdy by měli dospělí učit dítě mimo jiné porozumět emocím, uvědomovat si city své i druhých, umět o nich komunikovat. Současně je problémem tohoto věku i to, že děti opakují myšlenky, které slyšely od dospělých, kombinují je, jak uvádí Thorová (2015), díky schopnosti logického uvažování do nových a neotřelých souvislostí. Častým jevem je nevybíravé komentování svého zjevu, chování, schopností i oblečení. Děti, jak zmiňuje Goleman (1997), napodobují, co vidí doma, a tím si rozvíjejí svůj repertoár empatických reakcí. Jednou z cest k empatii je tedy prožitek a jeho sdílení - i z toho faktu vycházíme při práci s příběhem zaměřeným na vnímání odlišnosti. 
Titzl (1996) se odkazuje na východiska Komenského filozofie, v níž je pojmenována potřeba školní výchovou pomoci člověku, aby si jednou on mohl pomoci sám. Dle něho není možné přijmout nějakou provizorní morálku. Právě Komenského (1992) myšlenka všelidské odpovědnosti ukazuje, jak některé negativní vzorce chování procházejí dějinami. Vidí, jak ono selhání na bázi lidskosti narušuje lidské společenství. Odhalením antropologické podstaty krize společnosti Komenský nabízí společenské řešení. Člověk musí výchovou vstoupit do harmonie s celkem, otevř́t sám sebe, vystoupit sám ze sebe, nebýt jen pro sebe. Komenského „pan-sofie“, „pan-pedie“ je tak základem tolerance a přijímání druhých, nástrojem pro rozbourání bariér mezi lidmi.

\section{3 Čtením ke kritickému myšlení a k rozvoji sociálních dovedností}

Při našich úvahách a zaměření výzkumného šetření vycházíme i z faktu zmiňovaného Široňovou (1998), která dává výchovu dětí k toleranci do souvislosti s ovlivňováním jejich postojů. Komplexní charakter postojů přináší důraz na emoční rovinu působení, kdy se klíčovým stává prožitek, příběh, pocit’ovaná pozitivní atmosféra podmiňující otevřenost a jistotu. Tento poznatek rezonuje v potřebě rozvíjet u dětí klíčové emoční vlastnosti, kterými jsou podle Shapira (2009) vcítění, vyjadřování a chápání pocitů, ovládání nálady, nezávislost, přizpůsobivost, oblíbenost, schopnost řešení mezilidských problémů, vytrvalost, přátelskost, laskavost a úcta. To vše se odráží v práci s příběhem, v rámci které jsme využili poznatků mezinárodního programu RWCT. Stejně jako Cihá a Preissová Krejčí (2012, s. 119) jsme pracovali s metodou společného rozboru literárního př́iběhu. Oproti vyprávění příběhu, tedy naraci, jsme využili práci s psaným textem. Výuka probíhala pomocí třífázového modelu učení a myšlení E-U-R. Jak uvádí Grecmanová a Urbanovská (2007), tento model zahrnuje fáze Evokace - Uvědomění si významu - Reflexe. Respektování principů a posloupnosti uvedených fází pomáhá dosáhnout stanoveného cíle a vytvářet schopnost kriticky myslet. Principů RWCT bylo užito cíleně i z důvodů zmiňovaných Wildovou (2001), tedy proto, že se často stává, že žáci nedokáží dostatečně sledovat obsah čteného textu, získat čtením potřebné informace a ty dále využívat.

Za podstatné považujeme, $v$ souvislosti $s$ naším záměrem a tématem, tyto Kloosterovy myšlenky (2000, nestr.): „Když diskutujeme, čteme, debatujeme, 
nesouhlasíme a také si užíváme předávání a přijímání myšlenek, zapojujeme se do procesu, který prohlubuje a propracovává naše vlastní postoje a názory."

Hausenblas a Koštálová (2006) kladou důraz na reflexi, která se týká cílů učení, a to věcného obsahu, může se týkat i procesu učení. Odpovědi zjištěné $\mathrm{v}$ rámci práce $\mathrm{s}$ textem tak mohou sloužit současně jako diagnostický materiál pro učitele, jak zmiňuje Krejčová (2012a, 2012b), a to jak k diagnostice klimatu třídy, tak vztahů ve tř́íě.

Pomocí příběhů lze přispět u dětí k porozumění lidskému chování, světu, ale i sobě samým (O’Neill \& Lambert, 1982, in Ulrychová, 2007). Příběhy mohou nastínit možnosti řešení, nabízet alternativy a ukazovat nový úhel pohledu (Badegruber \& Pirkl, 2000).

\section{Metodologie výzkumu}

\subsection{Volba výzkumného tématu a výzkumné otázky}

Rozmanitost složení školních tříd a legislativní změny týkající se začleňování dětí se speciálními vzdělávacími potřebami nás vedly k výzkumnému šetření, ve kterém jsme se věnovali vnímání jinakosti dětmi na 1. stupni základní školy. Při volbě výzkumného designu a při stanovování výzkumného problému a výzkumných otázek jsme mimo jiné vycházeli z úvah Snyderové a Mitchella (2012, s. 206-207), kteří zmiňují, že výzkum

„postižení“ vázaný na lidský prvek se často nijak neliší od onoho vysávání času a energie, jež na sobě „postižení“ zažívali v minulosti a jež je jednou z hlavních př́čin jejich útlaku. [Vědci $\mathrm{z}$ oboru disability studies dnes dělají rozhovory S „postiženými“ dětmi o jejich zkušenostech se školou, pořádají četná setkání se zástupci etnických menšin.] Jinak řečeno, nedomníváme se, že by současný výzkum $\mathrm{v}$ oblasti disability studies ve vztahu $\mathrm{k}$ lidem s hendikepy tolik usiloval o patřičnou zdrženlivost a respektoval význam, jaký pro ně má sledování jejich vlastních cílů.

Zmiňují pak především zkoumání založené na textové analýze. My jsme zvolili pohled na stanovené téma skrze práci s příběhem, tedy metaforické zobrazení odlišnosti.

Pro práci s žáky 3.-5. třídy jsme využili upravený příběh z knihy Příběhy pomáhají s problémy (Badegruber \& Pirkl, 2000), a to na základě ukázky 
uvedené Čapkem (2015, s. 388-392) jako příklad dobré praxe - Listnáči ven! Výuka probíhala podle tříázového modelu učení a myšlení E-U-R. Děti četly na pokračování příběh, který otevíral témata k diskuzi týkající se odlišnosti. Na první straně se žáci dovídají, že se mezi jehličnatými stromy objevil nový strom, jiný, listnatý - třešeň. Jehličnany se mu smějí a listnáč zažívá pocit studu. Na druhé stránce jehličnany dávají třešni najevo, že ji tam nechtějí, že je to jejich půda, část z nich zakřičí Listnáči ven! Na třetí straně je třešeň terčem posměchu, a to ve chvíli, kdy na podzim opadá. Třešeň se cítí osamělá. Na posledním listu se objevuje v příběhu modřín, který upozorňuje, že i on, ač jehličnan, opadává - ostatní stromy se zamýšlí: „Možná, že je nám podobnější, než si myslíme."

Příběh otevírá témata, která považujeme v souvislosti s jinakostí za velmi důležitá, samotný text je metaforickým zobrazením lidské odlišnosti. Současně se snažíme respektovat to, co výše zmiňují Snyderová a Mitchell (2012).

V rámci stanoveného výzkumného problému Jak vnímají žáci 1. stupně odlišnost? jsme si stanovili výzkumné otázky, na které v příspěvku odpovídáme. Zjišt'ovali jsme, jak žáci 1 . stupně vnímají odlišnost; jakou mají zkušenost s odlišností; jak jsou schopni ve dvojicích argumentovat důvody pro odchod ze společenství těch, kteří je nepřijímají, a důvody pro setrvání v takovém prostředí. Dále jsme pomocí aktivity, v níž je tř́ída rozdělena na dvě části a žáci se přiklánějí k jednomu řešení, zjišt’ovali argumenty jednotlivců. Pomocí vzkazů lidem, kteří se chovají jako jehličnany v příběhu, jsme sledovali pohled žáků na druhé nepřijímající odlišnost. Vzhledem k tomu, že při práci s konkrétním textem jde i o čtení s předvídáním, je cílem výzkumného šetření i zachycení úvah žáků o dokončení př́iběhu. Za velmi důležitou považujeme také poslední část hodiny, reflexi. Během výzkumného šetření jsme si taktéž všímali rozdílů ve výpovědích žáků, které by mohly souviset s jejich věkem.

\subsection{Výzkumné metody, analýza dat a vyhodnocení}

Výzkumnými metodami využitými při výzkumném šetření byl skupinový rozhovor a pozorování. Hodiny vedla jedna z autorek textu, která je bývalou učitelkou 1. stupně základní školy a v současné době, kromě výuky na pedagogické fakultě, pracuje na částečný úvazek jako školní speciální pedagog. Ve všech školách, kde bylo výzkumné šetření realizováno, je součástí školního poradenského pracoviště psycholog, se kterým byla aktivita řešena, stejně tak jako situace po ní. Před jednotlivými hodinami byly zkontrolovány informované souhlasy zákonných zástupců žáků s natáčením ve výuce a $\mathrm{s}$ jejich 
využitím pro výzkumné účely. Pořízené videonahrávky byly následně přepsány, kódovány a kategorizovány pomocí programu ATLAS.ti. Prezentované výsledky vycházejí z kategorizace dat a struktura následného textu je sestavena podle klíčových témat, která vycházejí ze stanovených výzkumných otázek. Při interpretaci byla použita technika vyložení karet (Šed'ová, 2007).

\subsection{Výzkumný soubor}

Výzkumný soubor tvořili žáci 3. až 5. třídy třech základních škol v Českých Budějovicích. Celkem se jednalo o čtyři 3. třídy, 4. třídy a 5. třídy, tedy 12 tř́d o celkovém počtu 260 žáků. Jedna základní škola je složena pouze $\mathrm{z}$ tříd 1 . stupně základní školy (vždy pouze jedna třída v ročníku, v průměru 15 žáků ve třídě) a je specifická větším množstvím dětí ze sociokulturně znevýhodněného prostředí, dále jsou zde děti z jiných zemí. $V$ dalších dvou případech se jedná o větší úplné základní školy, kde v každém ročníku jsou tři až čtyři třídy (v průměru 24 žáků ve třídě). Přestože tř́́dy nebyly záměrně vybírány vzhledem ke struktuře žáků, v každé $\mathrm{z}$ dvanácti tříd se objevili žáci s odlišným mateřským jazykem.

\section{Výzkumná zjištění}

Během rozhovoru, který následoval po přečtení první části a který navedl žáky k přemýšlení o jinakosti, se děti vyjadřovaly $\mathrm{k}$ odlišnosti, v čem ji spatřují. Výpovědi je možné rozdělit do těchto kategorií: vnější odlišnost, kterou žáci zmiňovali nejčastěji; dále můžeme hovořit o vnitřní odlišnosti (třeba zlý a hodný). Třebaže některé interpretace je možné zařadit pod vnější odlišnosti, vytvořili jsme záměrně, vzhledem k přibývání dětí cizinců a žáků s postižením ve školách, dvě další kategorie, a to kulturní odlišnost a zdravotní odlišnost. Ve výpovědích týkajících se zdraví byla častěji patrná empatie: „Ve školce u nás byla slepá holčička, ona měla asistentku, aby do ničeho nevrážela a aby se jí nic nestalo. A mně jí bylo tak líto, ostatní si jí nevšímali, dělali si něco svého, ona byla s tou asistentkou, tak jsem k ní přišla a začala jsem si s ní hrát." Je zajímavé, že primárně žáci zmiňovali odlišnost vztahující se k tomu, jak se lišíme vizuálně. Kulturní a zdravotní odlišnost byla zmiňována méně. Velmi často byla zmiňována odlišnost v rámci rodiny („Můj brácha... protože každý má jiný záliby."). V nižších ročnících měli žáci tendenci uvádět podobné př́klady jako spolužáci, avšak učitelce se tuto situaci dařilo korigovat. 
Pokud se zaměříme na konkrétní zkušenosti s odlišností $v$ rodině, byli srovnáni sourozenci. Dále šlo o zážitky $z$ dovolené, kdy jsou děti konfrontovány $\mathrm{s}$ jinou kulturou. V rozhovorech byly uvedeny jak zkušenosti dětí $z$ mateřské školy, tak i ze školy základní. Byly případy, kdy žáci uvedli i vlastní odlišnosti: „Já jsem totiž vegetarián; Jsem jinej. Nikdo mě za to nebere vážně skoro." Nebáli se poukázat ani na odlišnost v rámci třídy, ale nebylo to to první, co by zmiňovali: „A setkali jste se s někým takovým?“ více žáků ukazuje na poslední lavici, kde sedí žák s poruchou autistického spektra: „My máme i ve třídě.“

Ve výpovědích je vidět vliv médií, rodičů, někteř́ žáci zmínili otázku Romů: „Hm, s cikány... mluví sprostě, nadávají si, jsou špinaví a nechovají se slušně“ a dále migrace: „S emigranty, protože jsou úplně jiný, že zabíjej lidi a tak, že se stěhujou někam..."

Po přečtení druhého listu se měli žáci vžít do pocitu třešně, jak se asi cítí. Záměrem bylo mimo jiné rozvíjení empatie. Téměř ve všech případech byla zmíněna samota, tíseň, strach, ohrožení, smutek, nezvyk, odstrčenost, pocit beznaděje. Dále si třešeň podle dětí kladla vnitřní otázky: Proč jsou vlastně na mě zlí? Současně podle nich mohla přemýšlet nad tím, jak to vyřeší, zda to nemá říct lesníkovi (tzn. svěřit se a hledat pomoc s řešením), zda má z lesa odejít, zda by si mohla sehnat kamaráda. Zajímavá byla reakce jednoho chlapce z 5. třídy: „Hmmm, tak to já znám. ... Cítí se stejně jako já. - Jako ty, a to znamená jak? - No odkopnutej, k ničemu. "Žákyně 5. tř́́dy, která se jinak během hodiny do diskuze zapojovala, polohlasně - jakoby pro sebe - uvedla: „Nejsem zvyklá mluvit o svých pocitech, nebudu mluvit ani o pocitech třešně." Pouze ojediněle žáci zmínili, že jim to nevadilo: „Nevadilo mi to“; „Každej, kdo je jinej, je výjimečnej“.

Z části hodiny, v níž vyučující s dětmi společně vyvozovala důvody, proč se jehličnaté stromy chovaly $\mathrm{k}$ třešni ošklivě, je možné $\mathrm{z}$ výpovědí vyvodit tyto kategorie: strach z neznámého, závist a žárlivost kvưli výhodám, neschopnost porozumění, vliv výchovy. Př́běh v této části dává př́ležitost popsat důvody, které mohou vést $\mathrm{k}$ tomu, že mají ostatní $\mathrm{k}$ někomu, kdo je odlišný, negativní postoj. Děti zažívají posměch kvůli vnějším odlišnostem (např. brýle, tloušt'ka), kvůli selhání při zkoušení a v prověrkách i kvůli neúspěchu v počítačových hrách. Jeden chlapec z 5 . třídy nastínil otázku sexuální orientace: „Mně třeba... ale to jako asi říká dneska každej každýmu klukovi, je to taková hrozně hloupá nadávka a mně to přijde úplně zbytečný, že když někdo někoho naštve, tak mu řekne, že to je gay, ale to je prostě takový, že mi to přijde 
úplně nejhloupější se někomu smát, i kdyby ten člověk byl v tomhle jinej, tak to přece je úplně hloupý se mu za to smát.“

Následovala argumentace důvodů (ve dvojicích) pro odchod jedinců ze společenství těch, kteří je nepřijímají, a důvodů pro setrvání v „nepřátelském“ prostředí. Opět se žáci zmiňovali primárně o třešni, ale ve většině případů předpokládáme projekci pocitů spojených s odchodem ze skupiny. Děti zapisovaly argumenty do připravené tabulky. $\mathrm{V}$ této části byla velmi akcentována naděje, přátelství jako důvod pro setrvání. V souvislosti s odchodem byla zmíněna nenávist, šikana. Současně byly uvedeny racionální důvody: „Nemá nohy“; „Aby byl les barevný“; „Protože jí tam lesník posadil“; ale i „Naučí se je ignorovat“; „Mohla by ze své odlišnosti udělat výhodu“. Náznak rovného přístupu byl zaznamenán naprríklad v tomto argumentu dvou žáků 4. tř́́dy: „Protože je to také strom a má právo být s ostatními." Pro odchod byl uveden i tento názor: „Jehličnany jsou rasisti a nemají rádi listnaté stromy!“ Téma rasismu, šikany bylo zmiňováno především v 5 . třídách.

Vzhledem $\mathrm{k}$ tomu, že $\mathrm{v}$ této chvíli šlo o diskuzní pavučinu, následovalo po argumentaci ve dvojicích rozdělení třídy na dvě poloviny, kdy se žáci měli rozhodnout, který postoj je jim bližší, zda má třešeň v lese zůstat, nebo odejít. V tuto chvíli se jednalo o vyjádření všech žákủ, kteří se vyjádřit chtěli. Získali jsme odpovědi od 145 žáků. Pro to, aby třešeň v lese zůstala, se vyjádřilo 98 žáků, 47 bylo pro to, aby z lesa odešla. Mezi důvody, proč by měla třešeň zůstat, se objevily výroky naznačující naději („může se změnit jejich chování, třeba se skamaráděj“), zvyk, vzájemné obohacení ("naučí se jejich řeč"), pomoc někoho jiného, pocit jedinečnosti, praktické důvody (,je zasazená“), důvod zvědavosti, ale i hlubší úvahy („Protože když by se prosadila tak by jí to zvedlo sebevědomí, zatím kdyby odešla, tak teoreticky by potom se bála jít do jiný společnosti další, že by jí nikdo zase nechtěl."). Důvodem k odchodu by bylo nepřijetí, nepř́ijemné pocity, osamocenost, neporozumění, objevil se i kontext šikany, rasismu („Chovaj se k ní hrubě, nemaj ji rádi, šikanovali ji, byli na ni zlí. Přece nebude mezi rasistama."). Děti taktéž zdůrazňovaly potřebu přátelství („Já si myslím, že je lepší odejít do toho listnatého lesa, protože bez kamarádů, to je jako byste byli na pustém ostrově.").

Z uvedených výpovědí je patrné, že děti často projektovaly sebe do pozice třešně. Opět je zde patrná víra ve zlepšení situace, naděje a velká akcentace přátelství. Pokud žáci přirovnali př́běh k situaci ve tř́idě, hlavní myšlenky, které žáci vyslovili, se týkaly obohacení od druhého, který je jiný, nového přátelství, 
další šance, ale na druhé straně se objevovaly i výroky „že by to nezvládala psychicky ani fyzicky“ nebo „že by se tam nechtěl nechat šikanovat“.

Po přečtení třetí části příběhu měli žáci za úkol navrhnout, jak příběh dopadne. $Z$ reakcí dětí je patrný vliv vlastního prožitku, případně představy přesahující do lidského života. Většina dětí viděla řešení v přijetí, a to na základě vyzdvihnutí silné stránky, výjimečnosti („Že když bude mít třešně, tak jim možná bude připadat zajímavá a možná se s ní skamarádí."), dále na základě nalezení něčeho společného - tento případ byl však ve všech třídách pouze jednou („,̌̌e třeba tu třešeň někdo povzbudí z těch stromů. Třeba je tam i nějakej jehličnan, kterej opadává. Modř́n? No, tak ten může ji povzbudit... Ona si už uvědomí, že tam může už zůstat.") - či podpory od dospělé osoby („Že to řekne tomu lesníkovi a on jim pak řekne, aby se k ní chovali slušně.“). Výpovědi jasně dokazují, že děti věří v dobro.

Během reflexe se žáci vyjadřovali $\mathrm{k}$ tomu, jaké měli $\mathrm{z}$ př́iběhu pocity. Zmiňovali pocit smutku („Mně to přišlo hodně smutný, protože ji odstrkovali, posmívali se jí a byli na ni zlí."), který se na konci proměnil v radost. Uváděli také pocit adrenalinového napětí i víry v dobrý konec. Hodně žáků uvedlo, že to byl př́iběh o nich, že se cítili jako třešeň. Během této reflexe začali spontánně zmiňovat, že z toho plyne ponaučení - „Že se nemáme vysmívat.“; „Že at' ty lidi vypadají jakkoliv, nebo i když jsou tlustý, stačí, že jsou hodní a milí."; „Nesud' nikoho podle toho jak vypadá zvenku.“; zaznělo i „Nesud'te knihu podle obalu...

Na závěr hodiny měli žáci za úkol na lísteček napsat anonymní vzkaz lidem, kteří se chovají jako jehličnaté stromy v příběhu. Ve vzkazech se objevovaly prosby: „LIDÉ! Chovejte se ke svým blízkým ohleduplně a hezky a nejen ke svým blízkým, ale i ke všem ostatním.“; výhružky: „Jste hnusný, a to se vám ve zlým vrátí!!!“; sprosté výrazy: „Děte do ******.“; ale i „Nebud'te rasisti!“ Bylo zajímavé, že některé děti své vzkazy směřovaly konkrétním spolužákům. V jiných byl patrný vliv rodiny a aktuálních událostí: „Lidé se někdy chovají úplně divně jako k prezidentovi M. Z., že pije, když to neví.“

\section{Diskuze a závěrečné shrnutí}

Při práci s jednotlivými tř́dami byl jednoznačně vidět vliv kolektivu, složení třŕdy. Byly třídy, v nichž se žáci přirozeně otevřeli, mluvili o svých pocitech, o odlišnosti jako o přirozenosti. Ve všech tř́́dách žáci mluvili o odlišnosti 
jako o něčem, co je běžné, normální, nepozastavovali se nad tím. Pokud se vyjadřovali o postižení, bylo cítit přijetí: „Já si myslím, že sem postižený patř́i, že jsou to prostě lidi taky.; "Já jsem včera jela autobusem a ona tady je celou dobu nějaká holčička z jiný země a já jsem si s ní povídala, moc jsem jí nerozuměla, ale jako udělala jsem jí radost." To, co je pro přijetí nejdůležitější, není to, co žákovi je, jak vypadá, ale jak se k druhým chová, zda ubližuje. Ve zkoumaných třídách bylo dále patrné, že vnímání odlišnosti se odvíjí od zkušeností, které žáci mají z rodiny, z docházky do mateřské školy a prvních ročníků v základní škole.

Z výzkumného šetření dále vyplynulo, že důvodem pro nepřijetí může být (kromě toho, když jeden druhému ubližuje) strach z neznámého: „Bylo to pro ně něco novýho. A když je vždycky něco novýho, tak se jakoby bojíme." Což je vlastně názor, který nacházíme u Vágnerové (1999), která dává do souvislosti postoje k odlišnosti s nízkou informovaností.

Ve chvíli, kdy žáci uvažovali nad návrhy řešení situace, byl odchod z takového prostředí zmiňován minimálně, výpovědi spíše obsahovaly naději, a to i jedno slovo, že někteří žáci uvedli svou vlastní negativní zkušenost, doprovázenou též somatizací prožívaného problému: „Já jsem šel sem proto, že to je, jako bys byl v hrozným stresu. Já když mám stres, tak mě strašně bolí břicho.“; „... třeba já tady nejsem jako moc prostě oblíbenej, taky mě nemaj moc rádi, ale zůstal jsem tady proto, že už jsem si zvykl na tu třídu." Ty, kteří vnímají odlišnost negativně, žáci považují za neslušné, hloupé.

Pokud šlo o dokončení příběhu, téměř všechny myšlenky žáků směřovaly $\mathrm{k}$ tomu, že jehličnaté stromy listnatý nakonec přijmou, projevovala se tedy víra v dobrý konec. Během celé vyučovací hodiny bylo velmi často skloňováno slovo přátelství, kamarádství, ukázalo se, jak velký význam mu žáci přikládají. Toto zjištění považujeme za velmi pozitivní, nebot' potřebu vytváření přátelských vztahů uvádí Shapiro (2009) jako jednu z důležitých emočních vlastností.

Na základě příběhu žáci také mluvili o své tř́ídě, měli tendenci poukazovat na to, čím jsou ti „jiní“ ve třídě výjimeční: „Že třeba Ronja je odněkud jinud. Ona nás může naučit... třeba nepálsky.“; „Jenom, že mě ted' napadlo, že pro Ronju jsme všichni jiní." (zde se vyjevuje uvědomění si i druhého pohledu). Během výzkumného šetření se potvrdilo to, na co upozorňuje Herényiová (2006) - žáci pomocí práce s prŕiběhem identifikovali a vyjadřovali vlastní pocity. 
Pokud jde o rozdíly výpovědí ve 3 . a 5 . ročníku, pak jako zásadní vnímáme pouze to, že žáci 5. ročníků spojovali nepřijetí odlišnosti se šikanou. I v písemných vzkazech se takové výroky objevovaly: „Zdravím Vás, šikanátoři, je odporné, jak se chováte, odlišným lidem ničíte sebevědomí a co, když jim vezmete chut' do života? Takhle jste nad tím nepřemýšleli, že? Zkuste se zamyslet nad tou situací z pohledu oběti. Díky!“

Výsledky výzkumného šetření ukazují, jak děti zapojené do výzkumu reagují na symbolicky prožívanou situaci spojenou s odlišností, jinakostí, nepřijetím. Reakce dětí ukázaly, že sociální prostředí mateřské i základní školy jim přináší přímé zkušenosti s dětmi s rozmanitými aspekty odlišnosti. Mezi zmiňovanými polohami jinakosti stále ještě dominují fyzická stigmata, věci viditelné, zřejmé, povrchové. Zároveň se ale objevuje schopnost identifikovat vnitřní odlišnosti, rozpoznatelné v projevech chování toho, kdo je jiný. Zcela zjevný je také prožitek multikulturní a multietnické odlišnosti typické pro současnou společnost. Děti také dokáží pojmenovat zdravotní handicapy, které vidí u dětí kolem sebe, a spojují je s vyčleňováním.

Za důležité zjištění považujeme to, že jinakost nevnímají zapojené děti jako fatální problém, objevují se sice též náznaky obav z neznámého, ale převládá důraz na konkrétní pozitivní zkušenosti s jinakostí z rodiny, sousedství, mateřské či základní školy. Tento typický projev utváření si světového názoru a rozšiřování vlastních sociálních kompetencí ukazuje důležitou výchovnou a emancipační roli školy. Ve výrocích dětí a jejich reakcích dominovala potřeba kamarádství, silný cit pro spravedlivost, většinový odpor k těm, kdo vztahy zneužívají a útočí na druhé. Děti jsou pevně svázány s prostředím, ve kterém ve školní třídě žijí, a jsou v něm ochotny přetrpět i negativní situace. Zde se objevuje velký důraz na učitelovu empatii, na jeho schopnost vnímat atmosféru ve třídě a pozitivně ovlivňovat sociální klima třídy. $Z$ charakteristik námi vybraných tř́id, které jsme získali od třídních učitelů, vyplývá, že zainteresovaní učitelé vnímají individuální specifika a odlišnosti žáků ve svých třídách a s ohledem na to i se svými třídami pracují.

Příkladem charakterizujícím možné změny v pohledech na jinakost u současné mladé generace mohou být i výsledky výzkumu, který v rámci projektu Multipolis, podpořeného ESF a MŠMT, realizoval Zelenda (2012). Data získaná na základě ř́zených rozhovorů a dotazníkových šetření s 35 žáky a studenty pražských základních škol a gymnázií (věk respondentů - 13 až 17 let) naznačují, jak děti $\mathrm{z}$ etnických menšin vnímají v dětském kolektivu samy 
sebe a jak jsou vnímány tímto kolektivem. Autor vyzdvihuje, že v této oblasti neodhalil závažné problémy, a poukazuje na následující fenomén: „děti z etnických menšin se cítí plně integrovány do kolektivu svých vrstevníků a stejně tak i jejich okolí je nevnímá podle toho, zda jsou Vietnamci, Arméni, Rusové atd., ale podle jejich osobních rysů a charakteristik“(s. 38).

Námi použitá metoda práce s př́během a využití principů RWCT mohou také posloužit jako př́klad toho, jak pracovat s tématem jinakosti/odlišnosti na 1. stupni základní školy. Jak vyplývá z průběhu i z výsledků výzkumného šetření, umožňuje učiteli nejen diskutovat takto složité téma s žáky, ale mimo jiné také pochopit, jak se cítí, jak smýšlejí o druhých, jak se cítí ve své třídě. Vytváŕí se tak prostor pro uchopení tohoto tématu a možnost pro intervenci, výchovné působení ze strany učitele.

\section{Literatura}

Alexander, J. C. (2006). Promýšlení „způsobů začlenění“: asimilace, napojování a multikulturalismus jako varianty občanské participace. In R. Marada (Ed.), Etnická různost a občanská jednota (s. 49-71). Brno: Centrum pro studium demokracie a kultury.

Badegruber, B., \& Pirkl, F. (2000). Př́íběhy pomáhají s problémy. Praha: Portál.

Cihá, M. (2012). Empatie jako cesta k respektu jinakosti a odlišnosti. In A. Krejčí Preissová, M. Cihá, \& L. Gulová, Jinakost, predsudky, multikulturalismus (s. 159-164). Olomouc: Univerzita Palackého v Olomouci.

Cihá, M., \& Preissová Krejčí, A. (2012). Realizace multikulturní výchovy, zážitková pedagogika a aktivizační metody ve výuce. In A. Preissová Krejčí, M. Cihá, \& L. Gulová, Jinakost, předsudky, multikulturalismus (s. 109-129). Olomouc: Univerzita Palackého v Olomouci.

Čapek, R. (2015). Moderní didaktika: Lexikon výukových a hodnoticích metod. Praha: Grada.

Čačka, O. (1999). Imaginace a škola. In O. Čačka a kol., Psychologie imaginativní výchovy a vzdělávání s př́íklady aplikace (s. 185-210). Brno: Doplněk.

Davis, L. J. (2012). Konstrukty normality. Gaussova křivka, román a vynález „postiženého“ těla v 19. století. In K. Kolářová (Ed.), Jinakost, postižení, kritika: Společenské konstrukty nezpůsobilosti a hendikepu. Antologie textů z oboru disability studies (s. 71-103). Praha: Sociologické nakladatelství.

Eco, U. (Ed.). (2007). Dějiny ošklivosti. Praha: Argo.

Goleman, D. (1997). Emoční inteligence. Praha: Columbus.

Grecmanová, H., \& Urbanovská, E. (2007). Aktivizační metody ve výuce, prostředek ŠVP. Olomouc: Hanex.

Hausenblas, O., \& Koštálová, H. (2006). Co je E-U-R. Kritické listy, 24, 67-69.

Herényiová, G. (2006). Humanistické alternativní školy. In E. Gajdošová \& G. Herényiová (Eds.), Rozvíjení emoční inteligence žáků (s. 21-44). Praha: Portál

Klooster, D. (2000). Co je kritické myšlení. Kritické listy, 1-2.

Kolářová, K. (Ed.). (2012). Jinakost, postižení, kritika: společenské konstrukty nezpůsobilosti a hendikepu. Antologie textů z oboru disability studies. Praha: Sociologické nakladatelství. 
Kolářová, K. (2012). Disability studies: Jiný pohled na „postižení“. In K. Kolářová (Ed.), Jinakost, postižení, kritika: společenské konstrukty nezpůsobilosti a hendikepu. Antologie textů z oboru disability studies (s. 11-40). Praha: Sociologické nakladatelství.

Komenský, J. A. (1992). Obecná porada o nápravě věcí lidských. Praha: Svoboda.

Krejčová, L. (2012a). Klima tř́dy. In V. Mertin \& L. Krejčová (Eds.), Metody a postupy poznávání žáka: pedagogická diagnostika (s. 222-230). Praha: Wolters Kluwer ČR.

Krejčová, L. (2012b). Vztahy ve třídě. In V. Mertin \& L. Krejčová (Eds.), Metody a postupy poznávání žáka: pedagogická diagnostika (s. 230-237). Praha: Wolters Kluwer ČR.

Prouzová Květoňová, R. (2011). Význam jinakosti pro speciálněpedagogické myšlení. Praha: PedF UK.

Přibáň, J. (1997). Hranice práva a tolerance. Praha: Sociologické nakladatelství.

Shapiro, L. E. (2009). Emoční inteligence dítěte a její rozvoj. Praha: Portál

Slowík, J. (2010). Komunikace s lidmi s postižením. Praha: Portál.

Snyder, S. L., \& Mitchell, D. T. (2012). Povinná primitivizace. In K. Kolářová (Ed.), Jinakost, postižení, kritika: společenské konstrukty nezpůsobilosti a hendikepu. Antologie textů z oboru disability studies (s. 184-214). Praha: Sociologické nakladatelství.

Šed’ová, Klára. (2007). Analýza kvalitativních dat. In R. Švaříček, K. Šed’ová a kol., Kvalitativní výzkum v pedagogických vědách (s. 207-247). Praha: Portál.

Široňová, T. (1998). Děti a mládež a výchova k toleranci. In T. Šišková (Ed.), Výchova k toleranci a proti rasismu (s. 124-129). Praha: Portál.

Thorová, K. (2015). Vývojová psychologie. Praha: Portál.

Titzl, B. (1996). Postižený člověk a společnost v proměnách času. In J. Pešková \& P. Lipertová (Eds.), Hledání učitele: škola a vzdělání v proměnách času. Praha: Pedagogická fakulta UK v Praze.

Ulrychová, I. (2007). Drama a př́běh. Praha: Nakladatelství AMU.

Vágnerová, M. (1999). Psychopatologie pro pomáhající profese. Praha: Portál.

Wildová, R. (2001). Národní projekt rozvoje čtenářské gramotnosti ve Velká Británii. Pedagogická orientace, 11(4), 76-86.

Zelenda, J. (2012). Etnická, kulturní a sociální odlišnost a její vnímání žáky a studenty ZŠ a SŠ. Moderní vyučování, 18(2), 38-40.

\section{Primary school childrens' perception of otherness}

Abstract: The aim of the paper is to show the perception of otherness by primary school children. The paper can also be seen as a basis for teaching practice and thus as an example of how to work with the topics of otherness and difference in primary school. The paper presents the research results from 12 primary schools Czech language lessons (in 3rd-5th grade). The entire teaching unit devoted to the work with a story was recorded and verbal expressions of pupils were transcribed. In the lesson the children were asked questions about their perception of otherness in the context of the story's content. The text, by its essence, gives room for the expression of feelings associated with otherness, creates incentives for argumentation of 
attitudes oriented towards keeping oneself in a situation of non-acceptance by the neighbourhood. The research focuses on the following questions: how primary school pupils perceive otherness, what their subjective experience with otherness is, what their proposals about solving the situation in the case of non-acceptance by the neighbourhood are, what they think about others who do not accept otherness. Given that it is both working with a specific text and reading with anticipation, the next topic analyzed is the proposed story ending. The results of the research show that the primary school pupils accept otherness without major problems, they are less able to cope with injustice. The research showed that in situations where they encounter non-acceptance, despite the difficulties experienced in the group, pupils prefer to stay in the neighbourhood they know.

Keywords: otherness, work with a story, social learning, social skills, primary school pupil

\section{Autoři}

PhDr. Miluše Vítečková, Ph.D., Jihočeská univerzita v Českých Budějovicích, Pedagogická fakulta, Katedra pedagogiky a psychologie, Jeronýmova 10, 37115 České Budějovice, e-mail: mviteckova@pf.jcu.cz

PhDr. Miroslav Procházka, Ph.D., Jihočeská univerzita v Českých Budějovicích, Pedagogická fakulta, Katedra pedagogiky a psychologie, Jeronýmova 10, 37115 České Budějovice, e-mail:mproch@pf.jcu.cz

Mgr. Marie Najmonová, Jihočeská univerzita v Českých Budějovicích, Pedagogická fakulta, Katedra pedagogiky a psychologie, Jeronýmova 10, 37115 České Budějovice, e-mail: mnajmonova@pf.jcu.cz 